\title{
Front Matter: Volume 8842
}

, "Front Matter: Volume 8842," Proc. SPIE 8842, Novel Optical Systems Design and Optimization XVI, 884201 (7 October 2013); doi:

$10.1117 / 12.2046791$

SPIE Event: SPIE Optical Engineering + Applications, 2013, San Diego, California, SPIE. United States 


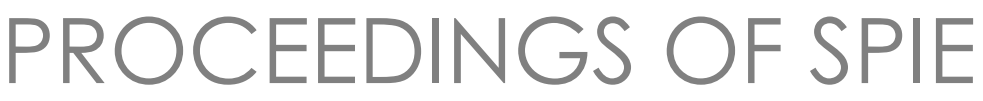

\section{Novel Optical Systems Design and Optimization XVI}

G. Groot Gregory

Arthur J. Davis

Editors

26-28 August 2013

San Diego, California, United States

Sponsored and Published by

SPIE 
The papers included in this volume were part of the technical conference cited on the cover and title page. Papers were selected and subject to review by the editors and conference program committee. Some conference presentations may not be available for publication. The papers published in these proceedings reflect the work and thoughts of the authors and are published herein as submitted. The publisher is not responsible for the validity of the information or for any outcomes resulting from reliance thereon.

Please use the following format to cite material from this book:

Author(s), "Title of Paper," in Novel Optical Systems Design and Optimization XVI, edited by G. Groot Gregory, Arthur J. Davis, Proceedings of SPIE Vol. 8842 (SPIE, Bellingham, WA, 2013) Article CID Number.

ISSN: 0277-786X

ISBN: 9780819496928

Published by

SPIE

P.O. Box 10, Bellingham, Washington 98227-0010 USA

Telephone +1 3606763290 (Pacific Time) · Fax +1 3606471445

SPIE.org

Copyright @ 2013, Society of Photo-Optical Instrumentation Engineers.

Copying of material in this book for internal or personal use, or for the internal or personal use of specific clients, beyond the fair use provisions granted by the U.S. Copyright Law is authorized by SPIE subject to payment of copying fees. The Transactional Reporting Service base fee for this volume is $\$ 18.00$ per article (or portion thereof), which should be paid directly to the Copyright Clearance Center (CCC), 222 Rosewood Drive, Danvers, MA 01923. Payment may also be made electronically through CCC Online at copyright.com. Other copying for republication, resale, advertising or promotion, or any form of systematic or multiple reproduction of any material in this book is prohibited except with permission in writing from the publisher. The CCC fee code is 0277-786X/13/\$18.00.

Printed in the United States of America.

Publication of record for individual papers is online in the SPIE Digital Library.

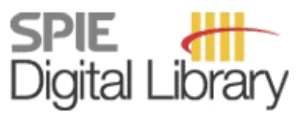

SPIEDigitalLibrary.org

Paper Numbering: Proceedings of SPIE follow an e-First publication model, with papers published first online and then in print and on CD-ROM. Papers are published as they are submitted and meet publication criteria. A unique, consistent, permanent citation identifier (CID) number is assigned to each article at the time of the first publication. Utilization of CIDs allows articles to be fully citable as soon as they are published online, and connects the same identifier to all online, print, and electronic versions of the publication. SPIE uses a six-digit CID article numbering system in which:

- The first four digits correspond to the SPIE volume number.

- The last two digits indicate publication order within the volume using a Base 36 numbering

system employing both numerals and letters. These two-number sets start with 00, 01, 02, 03, 04, $05,06,07,08,09,0 A, 0 B \ldots$. 0Z, followed by 10-1Z, 20-2Z, etc.

The CID Number appears on each page of the manuscript. The complete citation is used on the first page, and an abbreviated version on subsequent pages. Numbers in the index correspond to the last two digits of the six-digit CID Number. 


\section{Contents}

vii Conference Committee

ix Introduction

\section{SESSION 1 MICRO OPTICS}

884202 Cluster eye camera using microlenses on parabolic surface [8842-1]

H.-K. Shen, G.-D. J. Su, National Taiwan Univ. (Taiwan)

884203 Relating transverse ray error and light fields in plenoptic camera images (Invited Paper) [8842-2]

J. Schwiegerling, J. S. Tyo, College of Optical Sciences, The Univ. of Arizona (United States)

884204 Miniaturized optical fiber endoscope without inertial scan for simultaneous imaging and laser microsurgery [8842-3]

J. Adam, Christian-Albrechts-Univ. zu Kiel (Germany) and Univ. of California, Los Angeles (United States); P. Metz, M. Gerken, Christian-Albrechts-Univ. zu Kiel (Germany); B. Jalali, Univ. of California, Los Angeles (United States) and California NanoSystems Institute (United States)

884205 Discrete optimization method applied to optical design [8842-4]

Y.-C. Fang, National Kaohsiung First Univ. of Science and Technology (Taiwan); C.-M. Tsai, Kun Shan Univ. (Taiwan)

\section{SESSION 2 NOVEL SYSTEMS}

884207 The influence of phase mask position upon EDoF system [8842-6]

S.-H. Hsieh, Z.-H. Lian, National Chiao Tung Univ. (Taiwan); C.-M. Chang, MaxEmil Photonics Corp. (Taiwan); C.-H. Tien, National Chiao Tung Univ. (Taiwan)

884208 Special high speed imaging techniques using phase, aperture, and polarization effects [8842-7]

W. Zhao, D. C. Skaloud, S. Kutz, H. Rothe, Helmut-Schmidt-Univ. (Germany); C. F. Hahlweg, Helmut-Schmidt-Univ. (Germany) and bbw Hochschule Berlin (Germany)

884209 Laser autostereoscopic projection system [8842-8]

Y. Wang, J. Huang, Delta Electronics, Inc. (Taiwan)

8842 OA Applied paraxial methods and some philosophical questions [8842-9]

C. Hahlweg, bbw Hochschule Berlin (Germany) and Helmut-Schmidt-Univ. (Germany);

W. Zhao, Helmut-Schmidt-Univ. (Germany); J. Doerfler, bbw Hochschule Berlin (Germany);

H. Rothe, Helmut-Schmidt-Univ. (Germany) 
8842 OD Energy-minimized design in all-optical networks using unicast/multicast traffic grooming [8842-10]

W. S. Puche, F. O. Amaya, J. E. Sierra, Univ. Pontificia Bolivariana (Colombia)

8842 OE On modal analysis of coupled non-identical optical gradient waveguides [8842-1 1] N. D. Espinosa, Army Polytechnic School (Ecuador); J. A. Vila M., Univ. del País Vasco (Spain); T. E. Acosta, R. P. Leon, W. M. Urbina, C. N. Vega, Army Polytechnic School (Ecuador)

8842 OF ILP model for Greenfield WDM PON network design based on physical layer constraints [8842-12]

G. V. Arévalo, Univ. Politécnica Salesiana (Ecuador); J. E. Sierra, R. C. Hincapié, Univ. Pontificia Bolivariana (Colombia)

8842 OG Scenario analysis for performance evaluation of free-space quantum and classical communication channels [8842-13]

E. García, Univ. Autónoma de Baja California (Mexico); J. A. Lopez, Ctr. de Investigación Científica y de Educación Superior de Ensenada (Mexico); E. Álvarez, Univ. Autónoma de Baja California (Mexico); F. J. Mendieta, Agencia Espacial Mexicana (Mexico); A. Arvizu, Ctr. de Investigación Científica y de Educación Superior de Ensenada (Mexico)

$8842 \mathrm{OH} \quad$ Evaluation and optimization of the Savitzky-Golay smoothing filter for noise reduction in thin film interference signal analysis [8842-14]

P. I. Stavroulakis, P. Liatsis, City Univ. London (United Kingdom); N. Tipping, P. Craddock, Sencon (UK) Ltd. (United Kingdom)

\section{SESSION 4 OPTICS AND MUSIC}

8842 Ol The unique sound of the uni-vibe pedal: Part II. Transient behaviour [8842-15]

C. F. Hahlweg, bbw Hochschule Berlin (Germany) and Helmut-Schmidt-Univ. (Germany);

H. Rothe, Helmut-Schmidt-Univ. (Germany)

$88420 \mathrm{~J} \quad$ Visualization of sound generation: special imaging techniques [8842-16]

C. F. Hahlweg, Helmut-Schmidt-Univ. (Germany) and bbw Hochschule Berlin (Germany);

D. C. Skaloud, H. L. Gutzmann, S. Kutz, H. Rothe, Helmut-Schmidt-Univ. (Germany)

8842 OK Perception of power modulation of light in conjunction with acoustic stimulation [8842-17]

C. F. Hahlweg, bbw Hochschule Berlin (Germany) and Helmut-Schmidt-Univ. (Germany);

C. Weyer, H. Gercke-Hahn, G\&S Gesundheit und Sicherheit für Betriebe GmbH (Germany);

H. L. Gutzmann, A. Brahmann, H. Rothe, Helmut-Schmidt-Univ. (Germany)

\section{SESSION 5 COMPUTATIONAL TOOLS I}

$8842 \mathrm{OL}$ Toleranced freeform optical design with extended sources using ray targeting (Invited Paper) [8842-18]

R. J. Koshel, Photon Engineering LLC (United States) and College of Optical Sciences, The Univ. of Arizona (United States); S. Mulder, Photon Engineering, LLC (United States) 
$88420 \mathrm{M}$ Inspection and characterization of flexo-printing plates [8842-19]

C. Hahlweg, bbw Hochschule Berlin (Germany); L. Pescoller, Peret GmbH (Italy); W. Zhao, bbw Hochschule Berlin (Germany)

8842 ON Helical apodizers for tunable hyper Gaussian masks [8842-20]

J. Ojeda-Castañeda, S. Ledesma, C. M. Gómez-Sarabia, Univ. de Guanajuato (Mexico)

\section{SESSION $6 \quad$ REMOTE SENSING}

884200 Designing an acousto-optical spectrometer for Guillermo Haro Astrophysical Observatory [8842-22]

A. S. Shcherbakov, A. O. Arellanes Bernabe, V. Chavushyan, Instituto Nacional de Astrofísica, Óptica y Electrónica (Mexico)

8842 OP ESPRESSO APSU: simplify the life of pupil slicing [8842-23]

P. Conconi, M. Riva, INAF - Osservatorio Astronomico di Brera (Italy); F. Pepe, Observatory of Geneva (Switzerland); F. M. Zerbi, INAF - Osservatorio Astronomico di Brera (Italy); A. Cabral, Univ. of Lisbon (Portugal); S. Cristiani, INAF - Osservatorio Astronomico di Trieste (Italy); D. Megevand, Observatory of Geneva (Switzerland); M. Landoni, INAF -

Osservatorio Astronomico di Brera (Italy) and Univ. degli Studi dell'Insubria (Italy); P. Spanó, National Research Council Canada (Canada)

8842 OR Range reconstruction model for 3D gated imaging [8842-25]

C. Tan, Multimedia Univ. (Malaysia); T. Chai, Katholieke Univ. Leuven (Belgium); S. Chua, X. Wang, Monash Univ. (Malaysia); B. Goi, Univ. Tunku Abdul Rahman (Malaysia); G. Seet, Nanyang Technological Univ. (Singapore)

\section{SESSION 7 COMPUTATIONAL TOOLS II}

8842 OS Stereo matching image processing by selected finite length edge line matching on least square method [8842-26]

A. Akiyama, Kanazawa Technical College (Japan); N. Kobayashi, Kanazawa Institute of Technology (Japan); E. Mutoh, Kawasaki Heavy Industries Ltd. (Japan); H. Kumagai,

Tamagawa Seiki Co., Ltd. (Japan)

8842 OT A monochromatic recursive convolution finite-difference time-domain algorithm and its application in simulation of arrays of metal nano-particles [8842-27]

S. Banerjee, Sumitomo Chemical Co., Ltd. (Japan)

$8842 \mathrm{OU} \quad$ Modeling of the whispering gallery mode in microdisk and microgear resonators using a Toeplitz matrix formalism for single-photon source [8842-28]

M. Attia, A. Gueddana, R. Chatta, Sup'Com (Tunisia); A. Morand, IMEP-LAHC, CNRS, INPGUniv. Joseph Fourier (France) 
8842 OW Holograms: made from scratch [8842-30]

D. Tierney, Xavier Univ. (United States); E. Frins, Univ. de la República (Uruguay); W. Dultz, B. Hils, Johann Wolfgang Goethe-Univ. Frankfurt am Main (Germany); H. Schmitzer, Xavier Univ. (United States)

8842 0X System of polarization correlometry of biological liquids layers polycrystalline structure [8842-32]

A. G. Ushenko, T. M. Boychuk, O. P. Mincer, P. O. Angelsky, N. B. Bodnar, B. P. Oleinichenko, L. I. Bizer, Chernivtsi National Univ. (Ukraine)

8842 OY The system spatial-frequency filtering of birefringence images of human blood layers [8842-33]

A. G. Ushenko, T. M. Boychuk, O. P. Mincer, P. O. Angelsky, N. B. Bodnar, B. P. Oleinichenko, L. I. Bizer, Chernivtsi National Univ. (Ukraine)

884210 Singular microscopy of biological layers for diagnostics and classification of their optical properties [8842-35]

A. G. Ushenko, T. M. Boychuk, O. P. Mintser, Chernivtsi National Univ. (Ukraine)

884211 Multiparameter correlation microscopy of blood plasma polycrystalline networks in the diagnosis of cancer tissues of female reproductive system [8842-36]

G. D. Koval, V. N. Balazyuk, M. I. Sidor, Chernivtsi National Univ. (Ukraine)

884212 System of space-frequency filtering of linear and circular birefringence in cancer diagnosis [8842-37]

G. D. Koval, M. D. Raranskiy, Chernivtsi National Univ. (Ukraine)

884213 Polarization-phase imaging of biological fluids polycrystalline structure [8842-38]

M. Yu. Sakhnovskiy, V. N. Balazyuk, Chernivtsi National Univ. (Ukraine)

884214 Multidimensional Mueller-matrixes microscopy of biological phase-inhomogeneous layers [8842-39]

M. I. Sidor, O. V. Dubolazov, A. O. Karachevtsev, A. V. Motrich, Chernivtsi National Univ. (Ukraine)

884215 A novel and compact spectral imaging system based on two curved prisms [8842-40] Y. Nie, X. Bin, J. Zhou, Y. Li, Academy of Opto-Electronics (China) 


\title{
Conference Committee
}

\author{
Program Track Chairs
}

José Sasián, College of Optical Sciences, The University of Arizona (United States)

R. John Koshel, Photon Engineering LLC (United States) and College of Optical Sciences, The University of Arizona (United States)

\section{Conference Chairs}

G. Groot Gregory, Synopsys, Inc. (United States)

Arthur J. Davis, Reflexite Energy Solutions (United States)

\section{Conference Program Committee}

W. Andrew Cheng, PROSYS Optics Corporation (United States)

Jyh-Long Chern, Power Lens Technology, Inc. (Taiwan) and National Chiao Tung University (Taiwan)

Peter I. Goldstein, Philips Color Kinetics (United States)

Frank S. Grochocki, Ball Aerospace \& Technologies Corporation (United States)

Andrew R. Harvey, University of Glasgow (United Kingdom)

Cornelius F. Hahlweg, Helmut-Schmidt-Universität (Germany)

Richard C. Juergens, Raytheon Missile Systems (United States)

R. John Koshel, Photon Engineering LLC (United States) and College of Optical Sciences, The University of Arizona (United States)

Scott A. Lerner, nLIGHT Corporation (United States)

Rongguang Liang, College of Optical Sciences, The University of Arizona (United States)

Paul K. Manhart, NASA Langley Research Center (United States)

Rubén Mohedano, Light Prescriptions Innovators Europe, S. L. (Spain)

Jorge Ojeda-Castañeda, Universidad de Guanajuato (Mexico)

Craig Olson, L-3 WESCAM Sonoma Operations (United States)

Andrew Rakich, European Southern Observatory (Germany)

Michael D. Robinson, Ricoh Innovations, Inc. (United States)

Kevin P. Rolland-Thompson, Synopsys, Inc. (United States)

José Sasián, College of Optical Sciences, The University of Arizona (United States)

David L. Shealy, The University of Alabama at Birmingham (United States)

Andrew W. Sparks, L-3 WESCAM Sonoma Operations (United States)

Marija Strojnik Scholl, Centro de Investigaciones en Óptica, A.C. (Mexico) 


\author{
Session Chairs \\ 1 Micro Optics \\ Arthur J. Davis, Reflexite Energy Solutions (United States) \\ 2 Novel Systems \\ Peter I. Goldstein, Philips Color Kinetics (United States) \\ 3 Telecommunications \\ Andrew W. Sparks, L-3 WESCAM Sonoma Operations (United States) \\ 4 Optics and Music \\ Andrew W. Sparks, L-3 WESCAM Sonoma Operations (United States) \\ 5 Computational Tools I \\ Peter I. Goldstein, Philips Color Kinetics (United States) \\ 6 Remote Sensing \\ G. Groot Gregory, Synopsys, Inc. (United States) \\ 7 Computational Tools II \\ Craig Olson, L-3 WESCAM Sonoma Operations (United States)
}




\section{Introduction}

This year in San Diego, California, we held the 16th conference of Novel Optical Systems Design and Optimization. The conference was very well attended and featured oral presentation topic tracks in: Micro Optics, Novel Systems, Telecommunications, Optics and Music, Computational Tools, and Remote Sensing. In addition, there was a poster session, a joint Optical Engineering Plenary Session, and Technical Group Events.

This year's session on Music and Optics explored the effects of optics components in music with audio demonstrations and included research on the effects of sounds and light that may be encountered by audience members at clubs and concerts. The session on Telecommunications shared ideas on encrypted communications to improving the power and cost effectiveness in optical networks.

Two invited papers were presented during the conference;

- Dr. John Koshel from Photon Engineering and the College of Optical Sciences at the Univ. of Arizona presented his work on tolerancing freeform optical systems with extended sources using ray targeting.

- Dr. Jim Schwiegerling from the College of Optical Sciences at the University of Arizona discussed the relationship between transverse ray errors and light fields in plenoptic cameras.

The Novel Optical Systems Design and Optimization committee wanted to explore some new technology niches this year and this seems to have been a successful and positive endeavor. We look forward to continuing this effort next year!

Our thanks go to those who helped make this conference a success, especially the authors, audience, SPIE staff, and program committee. The authors share the credit for making this conference an unqualified success. The audience built upon this success by being active and asking engaging questions. The SPIE staff ensured that everything ran smoothly before, during, and after the meeting. The program committee provided excellent assistance to ensure the quality of the content while also presiding over a number of the sessions. It was composed of Andrew Cheng, Jyh-Long Chern, Peter Goldstein, Frank Grochocki, Andrew Harvey, Cornelius Hahlweg, Richard Juergens, John Koshel, Scott Lerner, Rongguang Liang, Paul Manhart, Rubén Mohedano, Jorge Ojeda-Castañeda, Craig Olson, Andrew Rakich, Michael Robinson, Kevin Rolland-Thompson. José Sasián, David Shealy, Andrew Sparks and Marija Strojnik Scholl. 
Next year we will return for the 17th iteration of this conference. The chairs will be Groot Gregory and Arthur Davis. The planning for Novel Optical Systems Design and Optimization XVII in 2014 is already underway, so please start planning submissions, questions, and your attendance. Focus themes are being decided at this time. If you would like to assist with the 2014 or later conference please contact one of us. We look forward to seeing you in 2014 !

\section{G. Groot Gregory Arthur J. Davis}

